\title{
$\alpha_{1 \mathrm{~A}}$-Adrenergic Receptors Regulate Cardiac Hypertrophy In Vivo Through Interleukin-6 Secretion
}

\author{
Robert S. Papay, Ting Shi, Michael T. Piascik, Sathyamangla V. Naga Prasad, \\ and Dianne M. Perez \\ Department of Molecular Cardiology, Lerner Research Institute, Cleveland Clinic Foundation, Cleveland, Ohio, (R.S.P., T.S., \\ S.V.N.P., D.M.P.); and Department of Pharmacology and the Vascular Biology Research Group, The University of Kentucky \\ College of Medicine, Lexington, Kentucky (M.T.P.)
}

Received December 14, 2012; accepted February 12, 2013

\section{ABSTRACT}

The role of $\alpha_{1}$-adrenergic receptors (ARs) in the regulation of cardiac hypertrophy is still unclear, because transgenic mice demonstrated hypertrophy or the lack of it despite high receptor overexpression. To further address the role of the $\alpha_{1}$-ARs in cardiac hypertrophy, we analyzed unique transgenic mice that overexpress constitutively active mutation (CAM) $\alpha_{1 \mathrm{~A}}$-ARs or CAM $\alpha_{1 \mathrm{~B}}-\mathrm{ARs}$ under the regulation of large fragments of their native promoters. These constitutively active receptors are expressed in all tissues that endogenously express their wild-type counterparts as opposed to only myocyte-targeted transgenic mice. In this study, we discovered that CAM $\alpha_{1 \mathrm{~A}}-\mathrm{AR}$ mice in vivo have cardiac hypertrophy independent of changes in blood pressure, corroborating earlier studies, but in contrast to myocytetargeted $\alpha_{1 \mathrm{~A}}$-AR mice. We also found cardiac hypertrophy in CAM $\alpha_{1 \mathrm{~B}}$-AR mice, in agreement with previous studies, but hypertrophy only developed in older mice. We also discovered unique
$\alpha_{1}$-AR-mediated hypertrophic signaling that was AR subtypespecific with CAM $\alpha_{1 \mathrm{~A}}$-AR mice secreting atrial naturietic factor and interleukin-6 (IL-6), whereas CAM $\alpha_{1 \mathrm{~B}}-\mathrm{AR}$ mice expressed activated nuclear factor $-\kappa \mathrm{B}(\mathrm{NF}-\kappa \mathrm{B})$. These particular hypertrophic signals were blocked when the other AR subtype was coactivated. We also discovered that crossbreeding the two CAM models (double CAM $\alpha_{1 \mathrm{~A} / \mathrm{B}}-\mathrm{AR}$ ) inhibited the development of hypertrophy and was reversible with single receptor activation, suggesting that coactivation of the receptors can lead to novel antagonistic signal transduction. This was confirmed by demonstrating antagonistic signals that were even lower than normal controls in the double CAM $\alpha_{1 \mathrm{~A} B}-\mathrm{AR}$ mice for $\mathrm{p} 38, \mathrm{NF}-\kappa \mathrm{B}$, and the IL-6/glycoprotein 130/signal transducer and activator of transcription 3 pathway. Because $\alpha_{1 \mathrm{~A} / \mathrm{B}}$ double knockout mice fail to develop hypertrophy in response to IL-6, our results suggest that IL-6 is a major mediator of $\alpha_{1 \mathrm{~A}}$-AR cardiac hypertrophy.

\section{Introduction}

The sympathetic nervous system plays a crucial role in the regulation of cardiac function. Norepinephrine (NE) released from sympathetic neurons innervating the heart enhances cardiac contractility, hypertrophy, and blood flow, and protects from ischemic injury. The effects of $\mathrm{NE}$ are mediated by nine different adrenergic receptors (ARs) $\left(\alpha_{1 \mathrm{~A}^{-}}, \alpha_{1 \mathrm{~B}^{-}}, \alpha_{1 \mathrm{D}^{-}}, \alpha_{2 \mathrm{~A}^{-}}\right.$, $\left.\alpha_{2 \mathrm{~B}^{-}}, \alpha_{2 \mathrm{C}}, \beta_{1^{-}}, \beta_{2^{-}}, \beta_{3^{-}} \mathrm{AR}\right)$. These receptors are part of a larger superfamily of $\mathrm{G}$ protein-coupled receptors that mediate the effects of hormones and neurotransmitters.

Three different $\alpha_{1}$-AR subtypes have been cloned (Cotecchia et al., 1988; Perez et al., 1991, 1994). The $\alpha_{1 \mathrm{~A}}$-AR and $\alpha_{1 \mathrm{~B}}-\mathrm{AR}$ are present in the myocyte (Michel and Insel, 1994; Michel et al., 1994). However, the lack of $\alpha_{1}$-AR subtype-selective antagonists has made it difficult to identify the physiologic roles of $\alpha_{1}$-AR subtypes in the heart. To circumvent this problem, several transgenic mouse models that either overexpress, knockout

This research was supported by the National Institutes of Health Heart, Lung, and Blood Institute [Grant R01-HL098279] (to D.M.P.).

dx.doi.org/10.1124/mol.112.084483.
(KO), or heart-target the $\alpha_{1}$-AR subtypes have been created and analyzed (Milano et al., 1994; Cavalli et al., 1997; Grupp et al., 1998; Wang et al., 2000; Lemire et al., 2001; Lin et al., 2001; Zuscik et al., 2001; Yun et al., 2003; O'Connell et al., 2006). Although most of these models agree that $\alpha_{1}$-ARs are 3important for physiologic heart function, there is some variance on their roles in cardiac hypertrophy. Whereas previous cellular studies using mildly selective ligands suggest that the $\alpha_{1 \mathrm{~A}} \mathrm{AR}$ is the mediator of hypertrophy in neonatal myocytes (Knowlton et al., 1993; Rokosh et al., 1996; Autelitano and Woodcock, 1998), the myocyte-targeted $\alpha_{1 \mathrm{~A}}-\mathrm{AR}$ transgenic mouse did not display hypertrophy (Lin et al., 2001) despite high levels of receptor overexpression. Most of the mouse models with the exception of one (Grupp et al., 1998) that overexpress or myocyte-target the $\alpha_{1 \mathrm{~B}}-\mathrm{AR}$ subtype demonstrated a mild, but significant cardiac hypertrophy.

We now further describe the role of the $\alpha_{1}$-ARs in cardiac hypertrophy utilizing unique transgenic mice that overexpress CAM $\alpha_{1 \mathrm{~A}}-\mathrm{ARs}$ or CAM $\alpha_{1 \mathrm{~B}}-\mathrm{ARs}$ under the regulation of their isogenic promoters to achieve both myocyte and nonmyocyte expression. Not only did we find cardiac hypertrophy in both

ABBREVIATIONS: ANF, atrial naturietic factor; AR, adrenergic receptor; BNP, brain naturietic peptide; BP, blood pressure; CAM, constitutively active mutation; ERK, extracellular signal-regulated kinase; gp130, glycoprotein 130; $\left[{ }^{125} \mathrm{l}\right]$-HEAT, 2-[ $\beta$-(4-hydroxy-3-[ $\left.{ }^{125} \mid\right]$ iodophenyl)ethylaminomethyl]tetralone; HW/BW, heart to body weight ratio; IL, interleukin; $\mathrm{IP}_{3}$, inositol-1,4,5-trisphosphate; KO, knockout; NE, norepinephrine; PE, phenylephrine; STAT3, signal transducer and activator of transcription 3. 
mouse models in contradiction to previous studies, we also discovered unique $\alpha_{1}$-AR-mediated hypertrophic signaling that was subtype-specific and focused on the IL-6 pathway for the $\alpha_{1 \mathrm{~A}}-\mathrm{AR}$ subtype. Of particular interest, the hypertrophy and associated signals were blocked when the other AR subtype was coactivated through agonism or through crossbreeding the two CAM models (double CAM $\alpha_{1 \mathrm{~A} / \mathrm{B}}-\mathrm{AR}$ ).

\section{Materials and Methods}

Transgenic Mice and Cross-Mating. The generation of CAM $\alpha_{1 \mathrm{~A}}-\mathrm{AR}$ and CAM $\alpha_{1 \mathrm{~B}} \mathrm{AR}$ mice has been described elsewhere (Zuscik et al., 2000; Rorabaugh et al., 2005). Normal littermates are used as controls. Tissue-specific distribution was achieved using large fragments of the mouse $\alpha_{1 \mathrm{~A}} \mathrm{AR}$ or $\alpha_{1 \mathrm{~B}} \mathrm{AR}$ promoters (Zuscik et al., 1999; O'Connell et al., 2001) to drive overexpression of cDNA that encodes the CAM receptors (Zuscik et al., 2000; Rorabaugh et al., 2005). All procedures on the mice conform to the Guide for the Care and Use of Laboratory Animals by the National Institutes of Health and were approved through the institutional animal use committee (ARC 08906).

Radioligand Binding. The protocols used for membrane preparation and radioligand binding were previously described (Rorabaugh et al., 2005). Saturation binding was performed using the $\alpha_{1}$-AR-selective radioligand 2 -[ $\beta$-(4-hydroxy-3- $\left[{ }^{125} \mathrm{I}\right]$ iodophenyl)ethylaminomethyl]tetralone $\left(\left[{ }^{125} \mathrm{I}\right]-\mathrm{HEAT}\right)$.

Measurement of Inositol-1,4,5-Trisphosphate. Heart tissue were weighed, chopped into small pieces, and incubated for 1 hour at $37^{\circ} \mathrm{C}$ in serum free Dulbecco's modified Eagle's medium containing $10 \mathrm{mM}$ $\mathrm{LiCl}$ with or without $10 \mu \mathrm{M}$ phenylephrine (PE). The inositol-1,4,5trisphosphate $\left(\mathrm{IP}_{3}\right)$ was measured using a radioreceptor assay kit from PerkinElmer Life Sciences (Boston, MA) according to the manufacturer's protocol.

Drug treatments and Measurement of Cardiac Hypertrophy. Six- to 8-month old CAM or normal mice were subjected to the following protocol. First, $\beta$-ARs were blocked in all experimental mice with propranolol ( $1 \mathrm{mg} / \mathrm{kg}$ body weight, i.p.). $\alpha_{1 \mathrm{~A}} \mathrm{ARs}$ were stimulated in CAM mice using cirazoline ( $0.3 \mathrm{mg} / \mathrm{kg}$ i.p.). $\alpha_{1 \mathrm{~B}}-\mathrm{ARs}$ were stimulated in CAM mice using $\mathrm{NE}(1 \mathrm{mg} / \mathrm{kg}$ i.p. $)$ and the $\alpha_{1 \mathrm{~A}} \mathrm{AR}$ antagonist, 5 -methylurapidil (10 $\mu \mathrm{g} / \mathrm{kg}$ i.p.). In separate studies, mice were injected i.p. with IL-6 ( $0.1 \mathrm{ml}, 40 \mathrm{ng})$. Control mice were injected with saline $(0.9 \% \mathrm{NaCl})$. All mice were injected twice daily for 2 weeks. Mice were then weighed, anesthetized with $0.2 \mathrm{ml}$ Nembutal (sodium pentobarbital; Lundbeck, Inc, Deerfield, IL), hearts removed, blotted free of blood five times, and weighed to determine heart to body weight ratio (HW/BW).

Echocardiography. Mice were subjected to echocardiographic analysis. The mice were anesthetized with isoflurane $(0.2 \% \mathrm{v} / \mathrm{v}) . \mathrm{Im}$ ages were acquired using an echocardiographic machine Vevo 770 (Visual Sonics, Toronto, ON, Canada). The m-mode echocardiograms obtained from 9 to 10 beats allowed quantification of mean and S.E.M. for left ventricle size, anterior and posterior wall thickness, and left ventricle cavity dilation.

Blood Pressure. The measurement of the mean carotid artery blood pressure (BP) in conscious mice was performed as described previously (Zuscik et al., 2001). The mice were anesthetized with 0.1 $\mathrm{mg} / \mathrm{g}$ ketamine and $2 \mu \mathrm{g} / \mathrm{g}$ acepromazine maleate. The recording began immediately after surgery and continued for a 7-hour period.

Fibrosis. Hearts were postfixed in ice-cold solution containing $2 \%$ paraformaldehyde, $75 \mathrm{mM}$ lysine, $37 \mathrm{mM}$ sodium phosphate, and 10 $\mathrm{mM}$ sodium peroxide, paraffin embedded, and processed for Masson's Trichrome staining to assess the extent of myocardial collagen deposition. Six $10-\mu \mathrm{m}$ transverse (short-axis) sections at the level of the papillary muscles were analyzed from each animal for bright blue staining using the Image $\mathrm{J}$ analysis program (NIH, Bethesda, MD).

Serum IL-6 Levels. Mice were injected with $0.2 \mathrm{ml}$ sodium pentobarbital solution (50 mg/ml) (Ovation Pharmaceutical, Deerfield,
IL) and blood samples were collected through the tail vein and set at room temperature for 2 hours. Levels of IL-6 in serum were determined by enzyme-linked immunosorbent assay using the Quantikine mouse kit from R\&D Systems (Minneapolis, MN) following the manufacturer's instructions.

Western Blot Analysis. Hearts were homogenized and processed as previously described (Gonzalez-Cabrera et al., 2003). After transfer, the blot was blocked and then incubated with one of the following primary antibodies overnight at $4^{\circ} \mathrm{C}$ : rabbit anti-Stat3 or glycoprotein 130 (gp130) at 1:1000, rabbit anti-p-Ser-Stat3 at 1:500, rabbit anti-pTyr-Stat3 at 1:500, mouse anti-phospho-IкB $\alpha$ at 1:1000, mouse anti-p38 or phospho-p38 at 1:1000, rat anti-IL-6 at $0.1 \mu \mathrm{g} / \mathrm{ml}$, or goat antiglyceraldehyde 3-phosphate dehydrogenase at 1:1000 (Cell Signaling Technologies, Danvers, MA). The blots were incubated with the appropriate secondary antibody for 1 hour at room temperature (IgG horseradish peroxidase at 1:10,000; Jackson ImmunoResearch, West Grove, PA). The blots were washed before incubation with the Pierce SuperSignal chemiluminescent reagents and exposed using CL-Xposure film (Pierce, Rockford, IL).

Statistical Analysis. Analysis of variance and the NewmanKeuls post-test were used to compare functional and signaling parameters. A probability value $<0.05$ was considered statistically significant. Prism software (GraphPad, San Diego, CA) was used for all data analyses.

\section{Results}

Crossbreeding and Characterization of CAM Mice. CAM $\alpha_{1 \mathrm{~A}}$-AR and CAM $\alpha_{1 \mathrm{~B}}$-AR homozygous mice were crossbred and subsequent generations intercrossed to produce bi-transgenic mice that contained both CAM $\alpha_{1 \mathrm{~A}}-\mathrm{AR}$ and CAM $\alpha_{1 \mathrm{~B}}-\mathrm{AR}$ homozygous alleles as determined by Southern blot analysis (Fig. 1). We performed radioligand binding to determine the total density of $\alpha_{1}$-AR receptors (Fig. 2A). In some tissue such as the heart, lung, and spleen, the $\alpha_{1}$-AR density in CAM $\alpha_{1 \mathrm{~A} / \mathrm{B}}-\mathrm{AR}$ mice was additive. In the higher expressing tissue such as brain or liver, $\alpha_{1}$-AR density was not additive in the CAM $\alpha_{1 \mathrm{~A} / \mathrm{B}}-\mathrm{AR}$, suggesting that some regulatory mechanism was present in those organs or the result of crossover events that affected promoter activity. Although mouse liver is considered an $\alpha_{1 \mathrm{~B}}-\mathrm{AR}$ dominant tissue, the $\alpha_{1 \mathrm{~A}}-\mathrm{AR}$ is present in the liver vasculature, natural killer cells, and B lymphocytes as well as other immune cells in the liver sinusoids (Grisanti et al., 2011). To determine the levels of receptor activity and constitutive signaling in the heart, we analyzed the amount of $\mathrm{IP}_{3}$ under basal and stimulated (PE, $\left.10 v \mathrm{M}\right)$ conditions. Although the basal $\mathrm{IP}_{3}$ activity for the various CAM mouse models was significantly increased compared with normal hearts, the level of stimulated activity was greater in CAM than normal mice but plateaued between the transgenic mouse models (Fig. 2B).

Characterization of Cardiac Hypertrophy. CAM $\alpha_{1 \mathrm{~B}}$-AR mice were previously shown to have mild yet significant cardiac hypertrophy (Zuscik et al., 2001). To determine whether the other CAM mouse models also had cardiac hypertrophy, we assessed heart/body weight ratios in similarly aged (6-8 months) mice (Fig. 3A). Both the CAM $\alpha_{1 \mathrm{~A}} \mathrm{AR}$ and $\mathrm{CAM} \alpha_{1 \mathrm{~B}}-\mathrm{AR}$ mice had significantly increased $\mathrm{HW} / \mathrm{BW}$ ratios compared with normal mice but the double CAM $\alpha_{1 \mathrm{~A} / \mathrm{B}}-\mathrm{AR}$ mice did not. A marker of maladaptive hypertrophy is fibrosis, which can be assessed through Masson Trichrome staining. Only the CAM $\alpha_{1 \mathrm{~B}}-\mathrm{AR}$ mice had significant fibrosis (Fig. 3B). We also determined mRNA expression of hypertrophyassociated fetal markers (Fig. 3C). Only CAM $\alpha_{1 \mathrm{~A}}$-AR had 


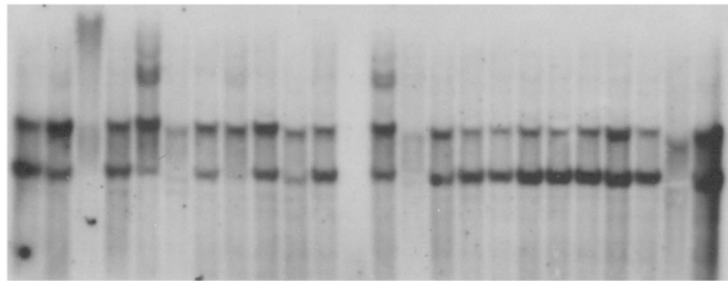

$\alpha_{1 A}$-AR probe

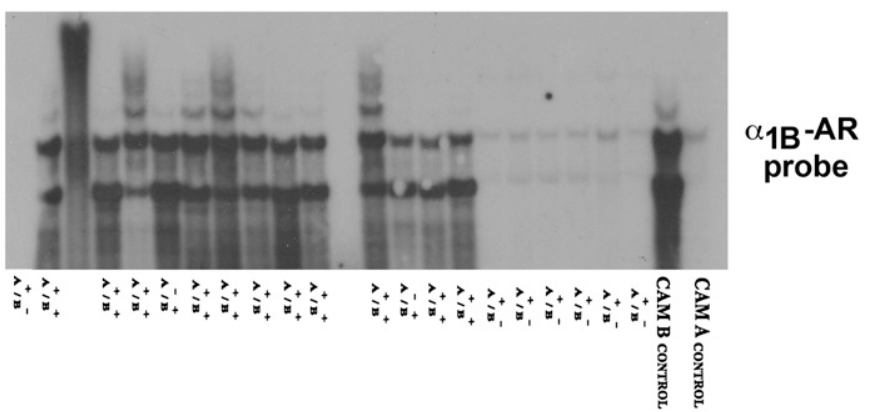

Fig. 1. Southern blot analysis of CAM $\alpha_{1 \mathrm{~A}} \mathrm{AR}$ and CAM $\alpha_{1 \mathrm{~B}}-\mathrm{AR}$ crossbreeding to produce double CAM $\alpha_{1 \mathrm{~A} / \mathrm{B}}-\mathrm{AR}$ transgenic mice. Pups from $\mathrm{CAM} \alpha_{1 \mathrm{~A}}-\mathrm{AR} \times \mathrm{CAM} \alpha_{1 \mathrm{~B}}-\mathrm{AR}$ breeding were genotyped from tail DNA and subjected to Southern blot analysis. Each pup DNA was screened against an $\alpha_{1 \mathrm{~A}}-\mathrm{AR}$-specific probe, designated as "A" on the blot (21) or an $\alpha_{1 \mathrm{~B}}-\mathrm{AR}$ specific probe, designated as "B" on the blot (14). Pup DNA that demonstrated positive results for both probes $\left(\mathrm{A}^{+} / \mathrm{B}^{+}\right)$were used as founders for the CAM $\alpha_{1 \mathrm{~A} / \mathrm{B}}-\mathrm{AR}$ mouse line and verified for homozygosity by back-breeding to wild-type mice.

weak but significantly elevated levels of atrial naturietic factor (ANF) and only the double CAM $\alpha_{1 \mathrm{~A} / \mathrm{B}}-\mathrm{AR}$ mice displayed significantly increased brain naturietic peptide (BNP). This is consistent with our previous report that the CAM $\alpha_{1 \mathrm{~B}} \mathrm{AR}$ mice did not display elevated ANF even though it had cardiac hypertrophy (Zuscik et al., 2001). To determine whether potential changes in BP affected hypertrophy, we measured both basal and induced BP with an indwelling catheter in the CAM $\alpha_{1 \mathrm{~A}}-\mathrm{AR}$ mice. Although basal BP in the $\mathrm{CAM} \alpha_{1 \mathrm{~A}}$-AR mice was lower, it was not significantly different from controls and CAM $\alpha_{1 \mathrm{~A}}$-AR mice also had no significant changes in BP from normal control mice when stimulated with phenylephrine (Fig. 3D). We previously published that $\mathrm{CAM} \alpha_{1 \mathrm{~B}}-\mathrm{AR}$ mice had decreased resting $\mathrm{BP}$ and pressure was blunted when stimulated by PE (Zuscik et al., 2001).

In addition to ANF and BNP levels, other hypertrophic signals previously associated with $\alpha_{1}$-AR activation were analyzed, such as p38 (Zechner et al., 1997; Clerk et al., 1998; Nemoto et al., 1998) and nuclear factor- $\kappa$ B (NF- $\kappa$ B) (Hirotani et al., 2002). In Western blot analysis, we found that the level of phospho-IKB $\alpha$ that regulates NF- $\kappa \mathrm{B}$ activity was substantially higher in the CAM $\alpha_{1 \mathrm{~B}}$-AR heart (Fig. 4), but was not elevated in the other mouse lines, even in the double $\mathrm{CAM} \alpha_{1 \mathrm{~A} / \mathrm{B}}-\mathrm{AR}$ mice. We also measured p-extracellular signalregulated kinase (ERK) and phospho-p38 levels (Fig. 4). Although phospho-p38 did not display any differences from normal mice in the single CAM mice, there was a significant decrease in phospho-p38 in the double $\mathrm{CAM} \alpha_{1 \mathrm{~A} / \mathrm{B}}-\mathrm{AR}$ mice. In contrast, p-ERK levels were not different between any of the mouse lines. These results suggest that specific inhibitory signal transduction is occurring in the double CAM $\alpha_{1 \mathrm{~A} / \mathrm{B}}-\mathrm{AR}$ mice that may be associated with its inhibition of the cardiac hypertrophy response.
Echocardiography. To confirm cardiac hypertrophy in vivo in the CAM mouse models, we performed echocardiography at two different age ranges. In agreement with the HW/BW ratios, CAM $\alpha_{1 \mathrm{~A}} \mathrm{AR}$ mice had significantly increased posterior wall dimensions at both 4-6 months and 11-12 months of age (Fig. 5, A and B). At older ages of 11-12 months, the CAM $\alpha_{1 \mathrm{~B}}-\mathrm{AR}$ mice displayed significantly increased wall thickness (Fig. 5, A and B). In chamber size, CAM $\alpha_{1 \mathrm{~A}}-\mathrm{AR}$ mice displayed increased left ventricular dimensions in both end systolic and end diastolic dimensions at both age ranges, whereas the $\mathrm{CAM} \alpha_{1 \mathrm{~B}} \mathrm{AR}$ mice only displayed increased chamber size at older ages and only for end diastole (Fig. 5, C-F). Double CAM $\alpha_{1 \mathrm{~A} / \mathrm{B}}-\mathrm{AR}$ mice did not display any increase in wall thickness or chamber size at any age and actually displayed significantly smaller chamber size than normal mice. There were no significant differences between males and females in any of the mouse models.

Costimulation of $\alpha_{\mathbf{1}}$-AR Subtypes Decreases HW/BW Ratio. Since the double CAM $\alpha_{1 \mathrm{~A} / \mathrm{B}}-\mathrm{AR}$ mice did not display cardiac hypertrophy whereas the single receptor CAM mice did, we tested the theory that co-expression of the $\alpha_{1}$-AR subtypes might lead to the repression of hypertrophy. First, normal mice were injected twice per day for 2 weeks with propranolol (to block $\beta$-AR effects) and either $\mathrm{NE}$ alone or NE in conjunction with the $\alpha_{1 \mathrm{~A}}-\mathrm{AR}$ antagonist 5-methylurapidil (to stimulate $\alpha_{1 \mathrm{~B}}$-ARs), or the $\alpha_{1 \mathrm{~A}}$-AR agonist cirazoline (to
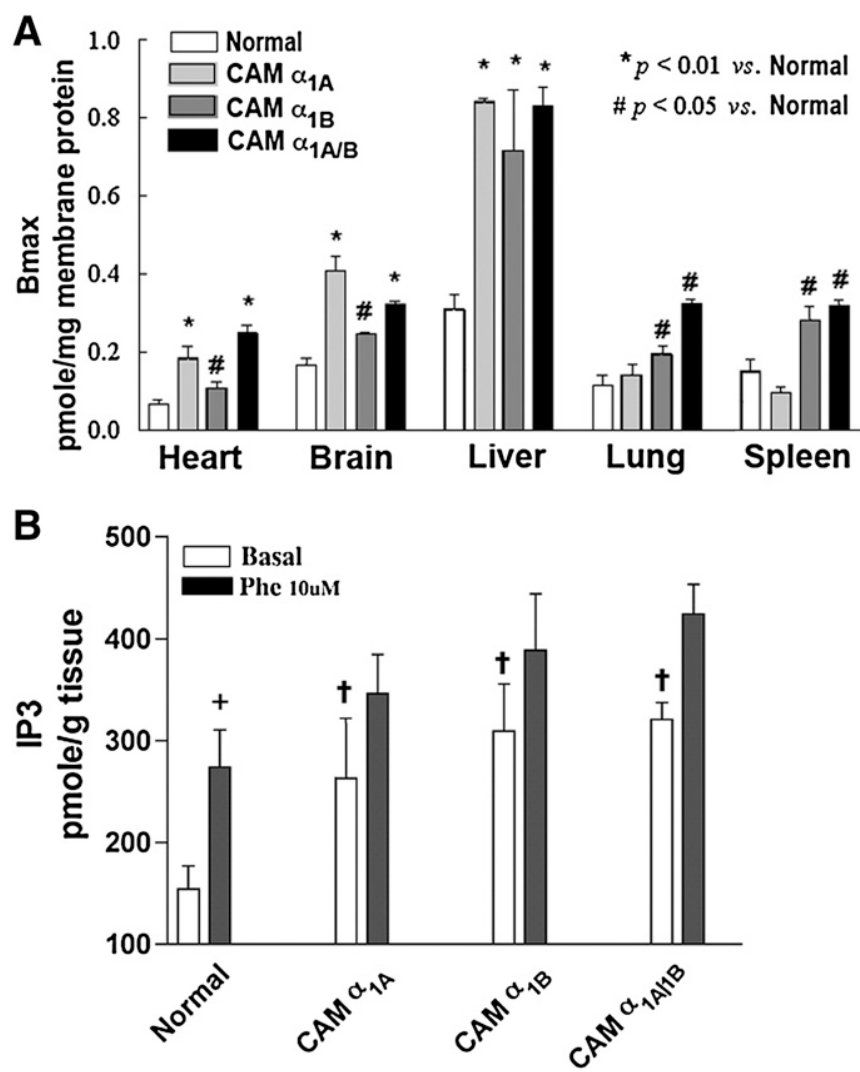

Fig. 2. Expression and constitutive activity of CAM $\alpha_{1 \mathrm{~A} / \mathrm{B}}-\mathrm{AR}$. (A) Saturation binding was performed using $\left[{ }^{125} \mathrm{I}\right]$-HEAT to determine the density of $\alpha_{1}$-ARs in hearts of transgenic and normal mice. $* P<0.01$; ${ }^{\#} P<0.05$ (significant difference compared with normal hearts). (B) $\mathrm{IP}_{3}$ concentrations were measured in heart tissue from transgenic and normal mice and normalized to wet tissue weight. ${ }^{+}$Significant activation of IP3 over nonstimulated tissue in normal hearts. ${ }^{\dagger}$ Significance of basal $\mathrm{IP}_{3}$ over nonstimulated tissue. Data represent the mean \pm S.E.M. of 4-8 mice of equal sexes. 
A

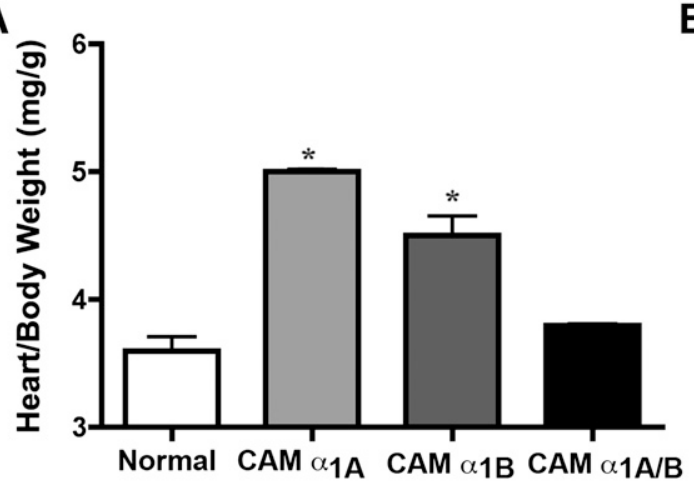

C

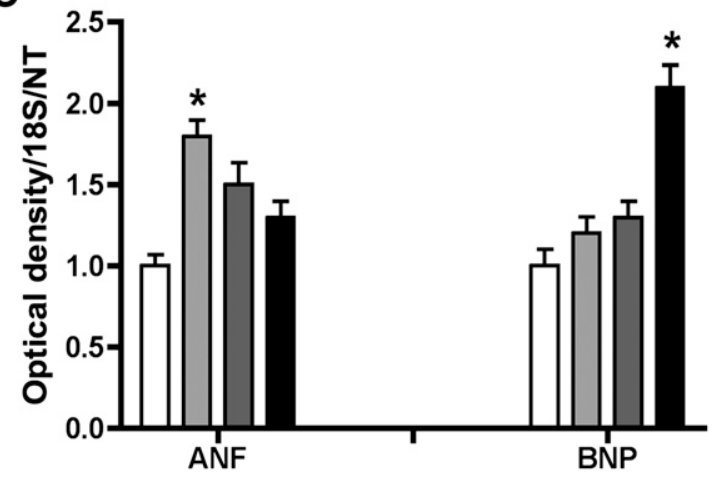

B

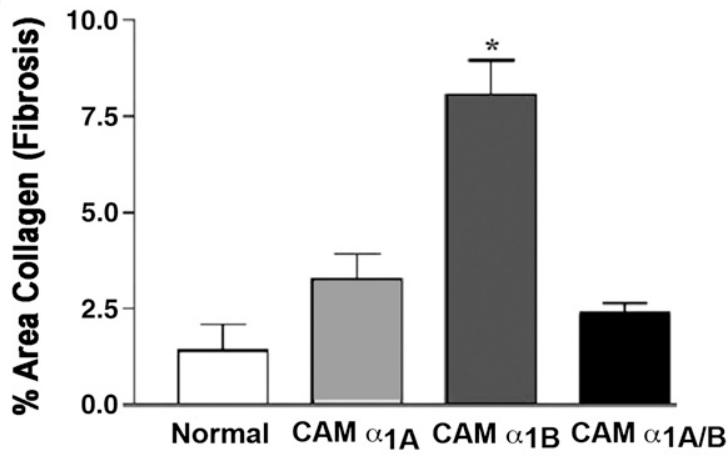

D

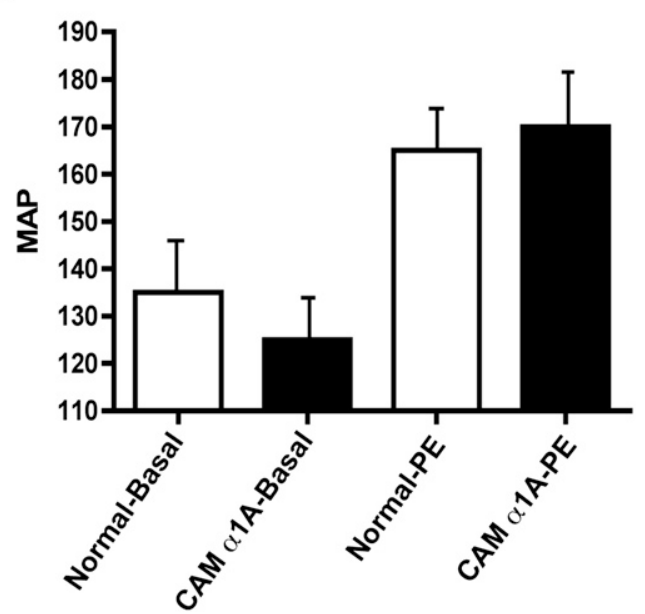

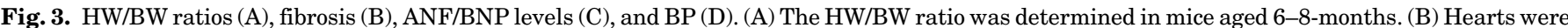

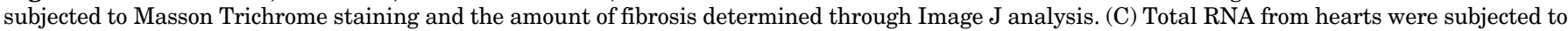

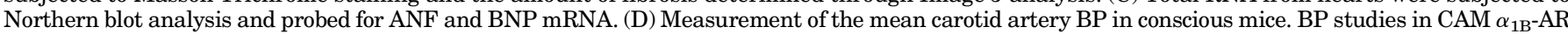

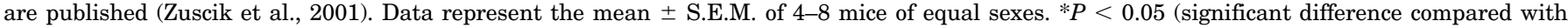
nontransgenic hearts).

stimulate $\alpha_{1 \mathrm{~A}}$-ARs). We found that normal mice induced cardiac hypertrophy to a similar degree with any subtype after $\alpha_{1}$-AR stimulation (Fig. 6A). We next used the same protocol and injected CAM $\alpha_{1 \mathrm{~A}}-\mathrm{AR}$ or CAM $\alpha_{1 \mathrm{~B}}-\mathrm{AR}$ mice with either cirazoline or the $\alpha_{1 \mathrm{~B}}-\mathrm{AR}$ stimulation cocktail. We found that only costimulation of the opposite $\alpha_{1}$-AR subtype significantly reduced the $\mathrm{HW} / \mathrm{BW}$ ratio (Fig. 6B), whereas additional stimulation of the same $\alpha_{1}$-AR subtype did not further increase hypertrophy. Finally, using the same protocol, we injected either cirazoline or the $\alpha_{1 \mathrm{~B}} \mathrm{AR}$ stimulation cocktail into the double CAM $\alpha_{1 \mathrm{~A} / \mathrm{B}}-\mathrm{AR}$ mice and found that stimulation of either $\alpha_{1}$-AR subtype increased cardiac hypertrophy (Fig. 6C).

IL-6 Levels. Since the IL-6/gp130/signal transducer and activator of transcription 3 (STAT3) pathway can mediate cardiac hypertrophy (Hirota et al., 1995; Kunisada et al., 1996) and we have previously shown that $\alpha_{1}$-ARs can couple to this pathway and regulate the secretion of IL- 6 in vitro (Gonzalez-Cabrera et al., 2003; Perez et al., 2009; Shi et al., 2012), we tested the level of IL-6 in the serum of the various mouse models. We found that only the CAM $\alpha_{1 \mathrm{~A}}-\mathrm{AR}$ mice had significant increased serum levels of IL-6 (Fig. 7A) whereas double CAM $\alpha_{1 \mathrm{~A} / \mathrm{B}}-\mathrm{AR}$ mice had levels similar to normal mice. These results suggest that IL- 6 may be a prominent component of the hypertrophy response for the $\alpha_{1 \mathrm{~A}}-\mathrm{AR}$ and not for the $\alpha_{1 \mathrm{~B}}-\mathrm{AR}$ and may explain why myocyte-targeted transgenic mice for the $\alpha_{1 \mathrm{~A}}$-AR did not display cardiac hypertrophy.

IL-6 Signaling. Besides involvement in the secretion of IL-6, $\alpha_{1}$-ARs can couple to the IL- 6 signaling pathway independent of IL-6 through protein kinase 3/ERK signaling (GonzalezCabrera et al., 2003; Perez et al., 2009; Shi et al., 2012). Therefore, we determined protein levels for gp130 and STAT3 in the various mouse models. We found that levels of gp130 as well as both phosphorylated forms of STAT3 in the hearts only from the double CAM $\alpha_{1 \mathrm{~A} / \mathrm{B}}-\mathrm{AR}$ mice were reduced compared with normal controls (Fig. 7B). These results suggest that the double CAM $\alpha_{1 \mathrm{~A} / \mathrm{B}}-\mathrm{AR}$ mice may be defective in gp130/ STAT3 signaling.

Double CAM $\alpha_{1 \mathrm{~A} / \mathrm{B}}-\mathrm{AR}$ Mice Are Defective for IL6-Mediated Cardiac Growth. We next determined whether the IL-6 signaling pathway is involved in $\alpha_{1}$-AR mediated hypertrophy and whether that pathway is defective in the double CAM $\alpha_{1 \mathrm{~A} / \mathrm{B}}-\mathrm{AR}$ mice. We injected exogenous IL-6 into mice for 2 weeks and determined its effects on heart growth. Both normal and CAM $\alpha_{1 \mathrm{~B}} \mathrm{AR}$ mice responded to IL- 6 treatment by increasing the $\mathrm{HW} / \mathrm{BW}$ ratio by $20-26 \%$, whereas CAM $\alpha_{1 \mathrm{~A}}$-AR mice were unresponsive to IL- 6 because they already possessed high IL-6 serum concentrations (Fig. 7C). Our results suggest that IL- 6 is a contributing factor to the $\alpha_{1}$-AR-mediated hypertrophic response. In addition, double 


\section{A}

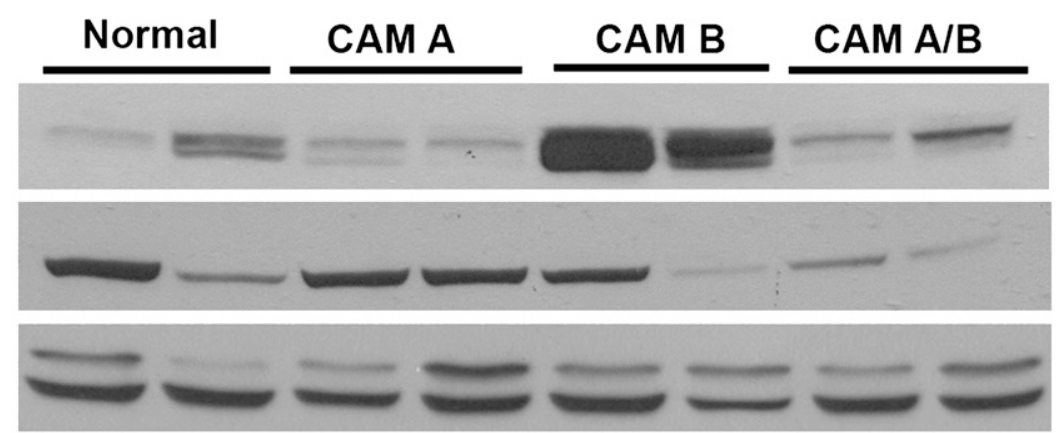

Phospho-IKB $\alpha$

\section{Phospho-p38}

\section{Phospho-ERK}

\section{Total p38}

B

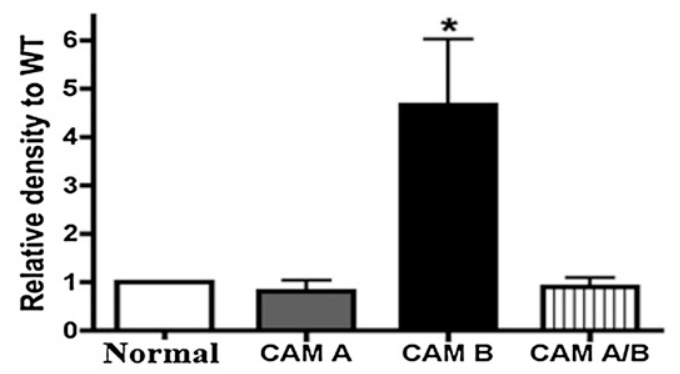

C

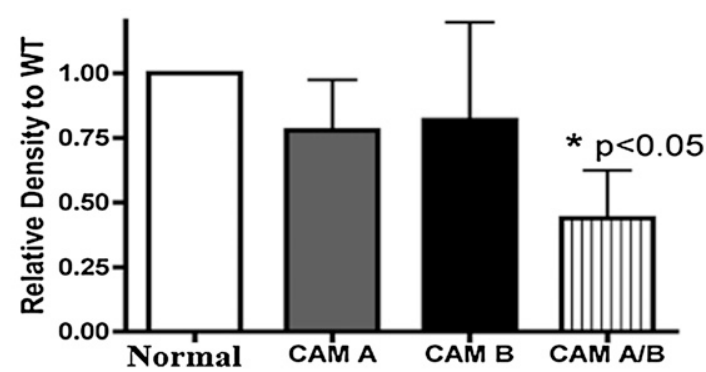

Fig. 4. Protein levels of phosphorylated $\mathrm{p} 38$ and IKB $\alpha$. Hearts were homogenized from normal, CAM $\alpha_{1 \mathrm{~A}}-\mathrm{AR}(\mathrm{CAM} A), \mathrm{CAM} \alpha_{1 \mathrm{~B}}-\mathrm{AR}(\mathrm{CAM} \mathrm{B})$, and CAM $\alpha_{1 \mathrm{~A} / \mathrm{B}}$-AR (CAM A/B) mice and subjected to Western analysis. Phosphorylated proteins were normalized to total protein and glyceraldehyde 3-phosphate dehydrogenase. Data represent the mean \pm S.E.M. of 4-6 mice of equal sexes. $* P<0.05$ (significant difference compared with control).

CAM $\alpha_{1 \mathrm{~A} / \mathrm{B}}-\mathrm{AR}$ mice was unresponsive to IL-6, confirming that the IL-6 pathway was defective and at least part of the mechanism for the inhibition of cardiac hypertrophy.

\section{Discussion}

Early studies (Simpson, 1983) demonstrated that incubation of myocytes with catecholamines caused cellular hypertrophy by activation of $\alpha_{1}$-ARs. Although many pathways have been shown to affect $\alpha_{1}$-AR mediated hypertrophy, several of these pathways merge into the mitogen-activated protein kinase pathways (Zechner et al., 1997; Clerk et al., 1998; Nemoto et al., 1998) but have not been previously associated with IL-6/gp130/STAT3 signaling. We recently showed that $\alpha_{1}$-AR-mediated protein kinase 3 and mitogenactivated protein kinase pathways activation can affect the phosphorylation status of STAT3 independent of IL-6 (Shi et al., 2012) and that $\alpha_{1}$-AR-mediated p38 and NF- $\kappa$ B activation can regulate the expression and secretion of IL-6 (Gonzalez-Cabrera et al., 2003; Perez et al., 2009).

Although previous studies suggest that the $\alpha_{1 \mathrm{~A}}$-AR subtype mediated hypertrophy in neonatal myocytes (Knowlton et al., 1993; Rokosh et al., 1996; Autelitano and Woodcock, 1998), myocyte-targeted mouse models suggested otherwise, independent from expression levels (Lin et al., 2001). In this study, we show for the first time that a mouse model of the $\alpha_{1 \mathrm{~A}} \mathrm{AR}$ subtype can mediate cardiac hypertrophy in vivo similar to CAM $\alpha_{1 \mathrm{~B}}$-AR mice (Zuscik et al., 2001). The $\alpha_{1 \mathrm{~A}}$-AR appears to mediate hypertrophy not through direct effects on the myocyte, consistent with the myocyte-targeted studies of Lin et al. (2001), but on secreted factors in the blood from noncardiac tissue, prominent of which is IL-6 (Fig. 8). As the native promoter in our transgenic mice allows systemic expression, $\alpha_{1}$-ARs are expressed in other cell types that may be required for secretion of paracrine factors that ultimately affect the myocyte, such as IL-6 (Fig. 8). IL-6 is secreted from various cell types regulated through $\alpha_{1}$-ARs (Loppnow and Libby, 1990; Yamauchi-Takihara et al., 1995; Hirasawa et al., 1996; Tayebati et al., 2000; Faber et al., 2001; Jensen et al., 2010; Grisanti et al., 2011), such as smooth muscle cells (Loppnow and Libby, 1990) and fibroblasts (Faber et al., 2001). IL-6 appears to play a prominent role in $\alpha_{1 \mathrm{~A}}$-AR-mediated hypertrophy since both normal and CAM $\alpha_{1 \mathrm{~B}}-\mathrm{AR}$ mice still respond to exogenous IL-6 (Fig. 7C), but not the CAM $\alpha_{1 \mathrm{~A}}-\mathrm{AR}$ mice, which were already saturated due to high serum levels (Fig. 7A). In addition, norepinephrine failed to initiate hypertrophy in IL-6 KO mice (Meier et al., 2009) and IL-6 failed to initiate a hypertrophic response in $\alpha_{1 \mathrm{~A} / \mathrm{B}} \mathrm{KO}$ mice (Fig. 7C), suggesting that IL- 6 is a prominent factor in $\alpha_{1}$-AR-mediated cardiac hypertrophy.

Interestingly, the signals associated with hypertrophy are different and unique in the two mouse models. The CAM $\alpha_{1 \mathrm{~A}}-\mathrm{AR}$ mice expressed ANF (Fig. 3C) and secreted IL-6 into the bloodstream (Fig. 7A). CAM $\alpha_{1 \mathrm{~B}}-\mathrm{AR}$ mice, while not secreting IL-6, robustly activated the NF- $\kappa \mathrm{B}$ (Fig. 4) hypertrophic pathway in the heart (Hirotani et al., 2002) and displayed fibrosis (Fig. 3). Although both IL- 6 and NF- $\kappa$ B are associated with hypertrophy, they have not been previously associated with $\alpha_{1}$-AR cardiac signaling. The selectivity of ANF expressing in the CAM $\alpha_{1 \mathrm{~A}}-\mathrm{AR}$ mice is not unexpected because 
A

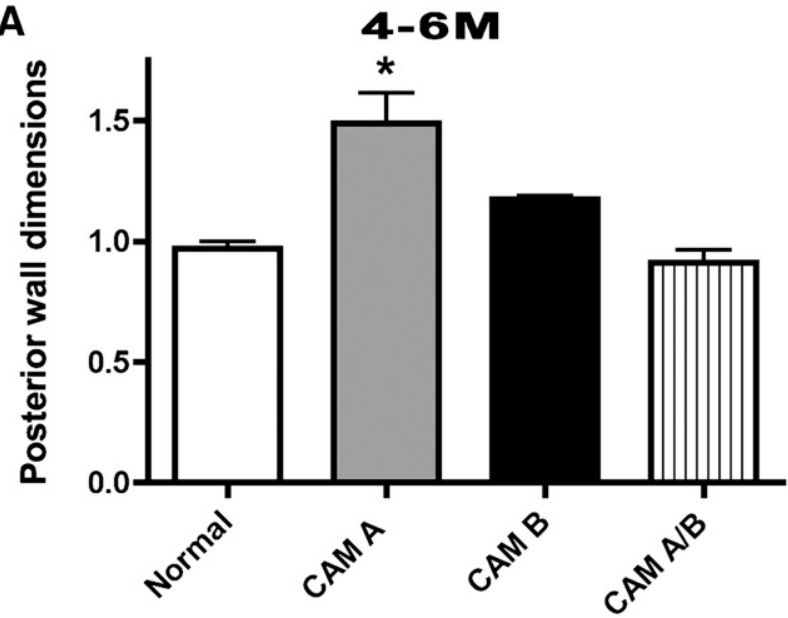

C

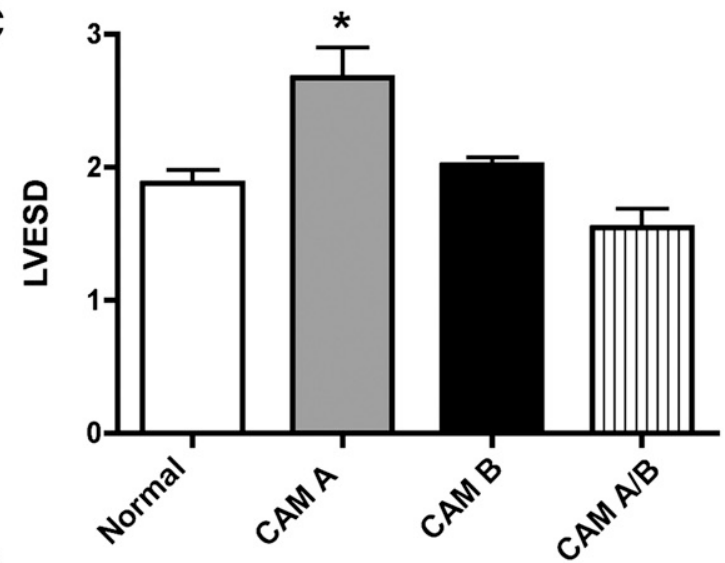

E

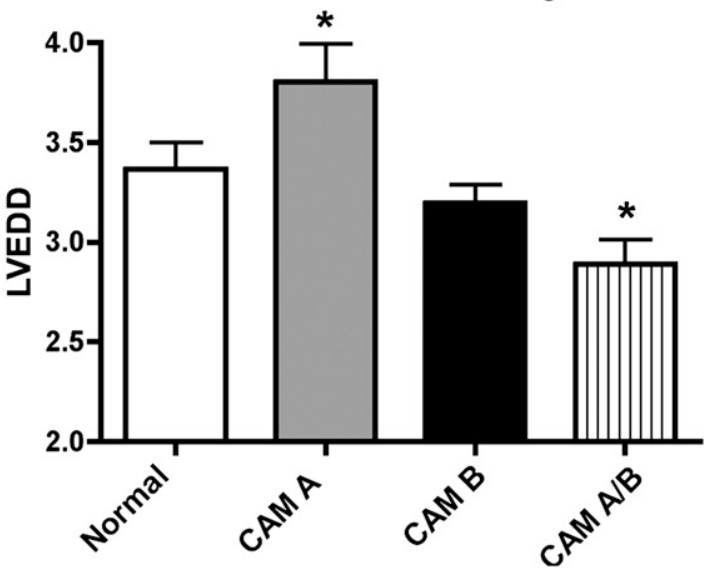

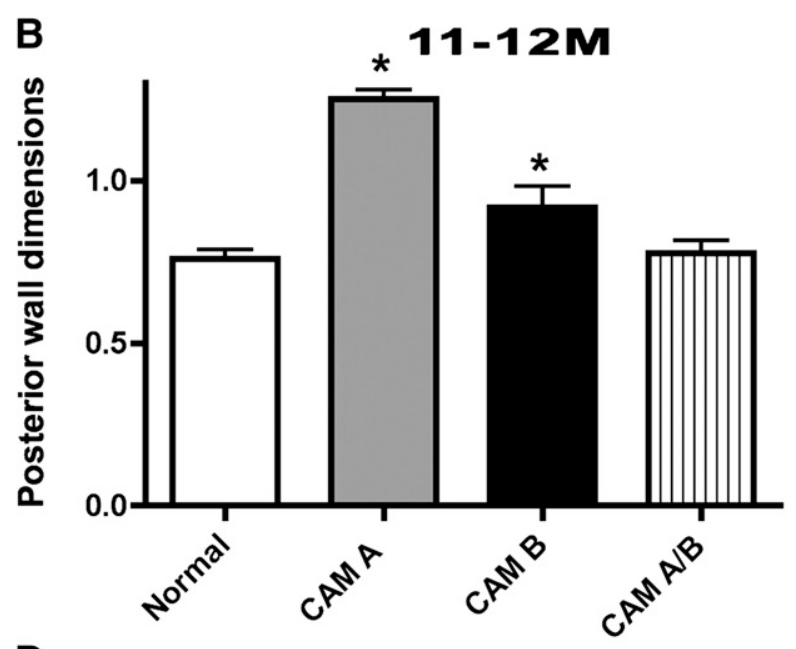

D
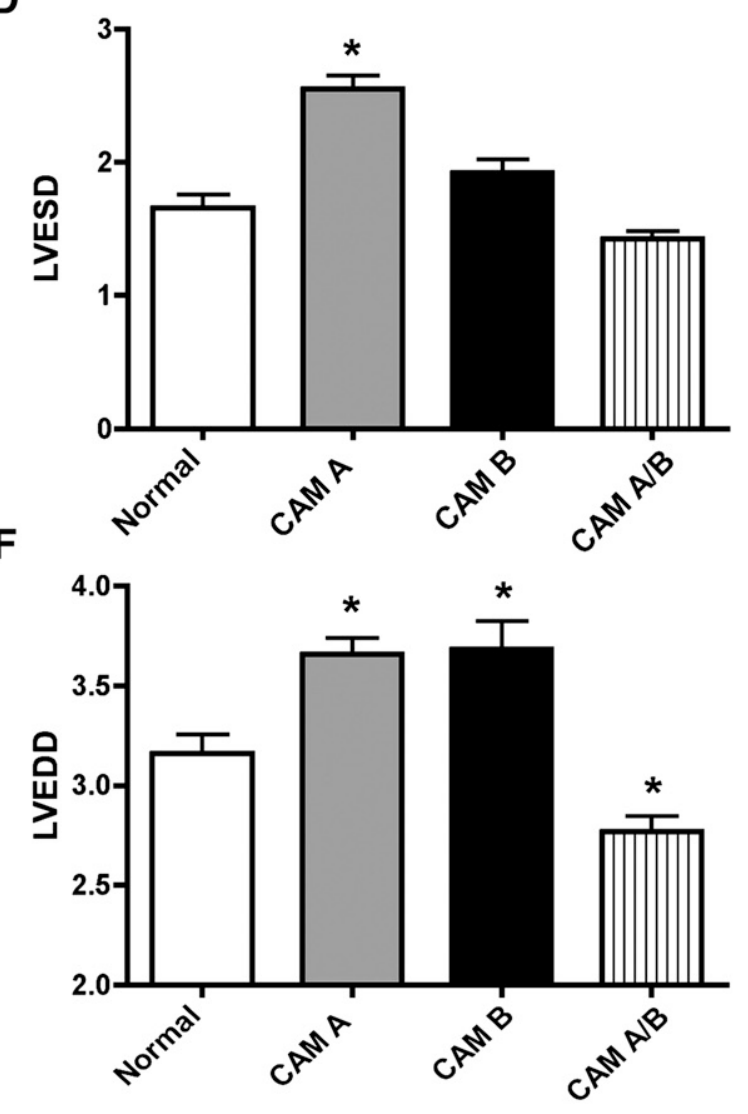

M-mode echocardiography

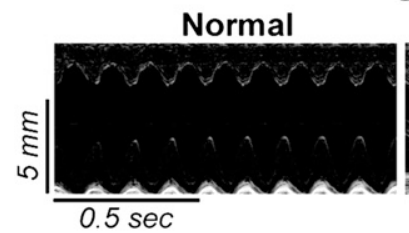

A line

B line

AB line
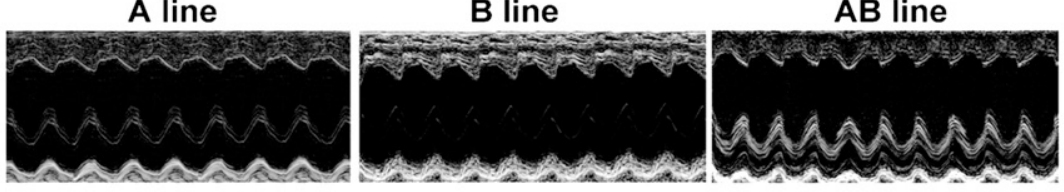

Fig. 5. Echocardiographic analysis of posterior wall dimensions and chamber size at ages 4-6 months and 11-12 months. Mice were subjected to echocardiographic analysis and anesthetized with isoflurane $(0.2 \% \mathrm{v} / \mathrm{v})$. M-mode echocardiograms (G) obtained from 9 to 10 beats per mouse allowed direct measurement (mean \pm S.E.M.) of posterior wall thickness (A and B) and ventricular dimensions end systolic dimensions $(\mathrm{C}$ and $\mathrm{D})$, and left ventricular end diastolic dimensions $(\mathrm{E}$ and $\mathrm{F}) . * P<0.05$ (significance compared with age-matched normal controls). $n=6-8$ mice of equal sexes. 
A

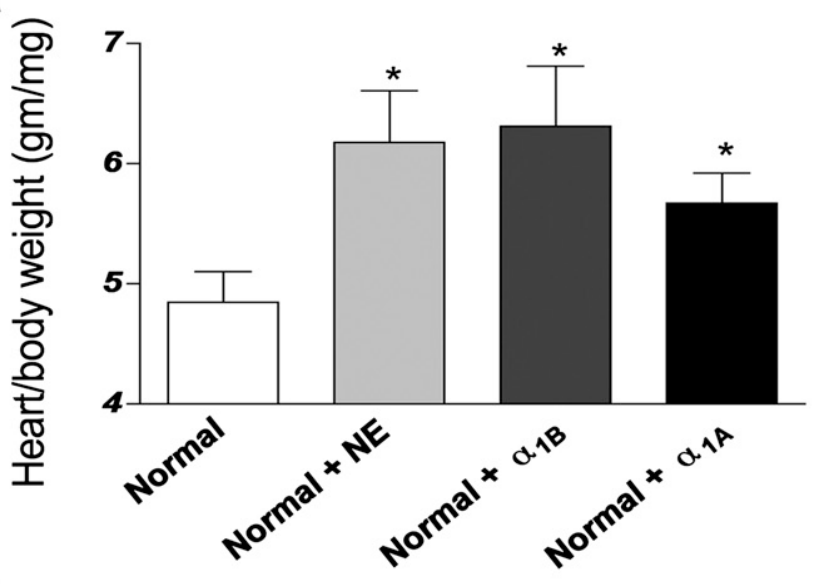

B

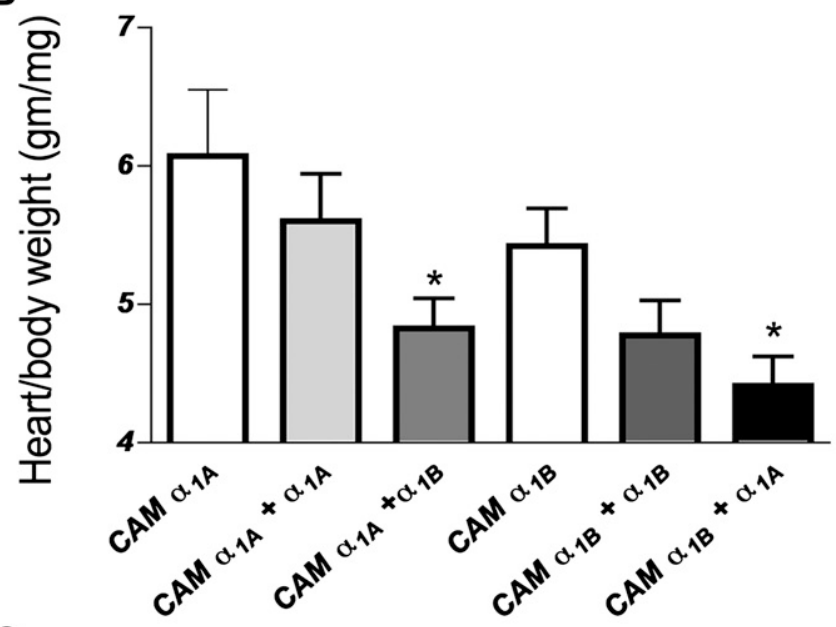

C

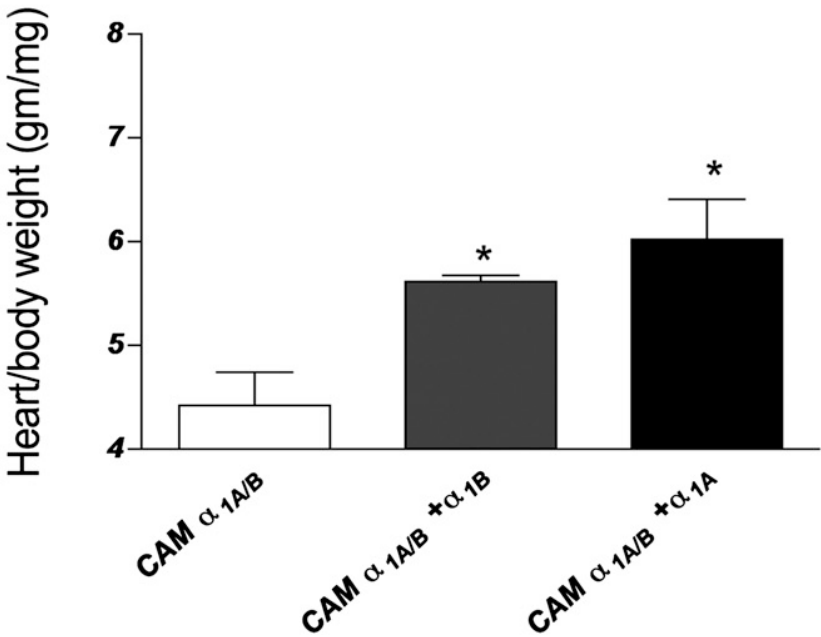

Fig. 6. $\alpha_{1}-\mathrm{AR}$ subtype induced cardiac hypertrophy and suppression by coactivation. Normal or CAM mice were subjected to i.p. injections of various $\alpha_{1}$-AR agonists and antagonists. $\alpha_{1 \mathrm{~A}}$-ARs were stimulated using cirazoline $\left(0.3 \mathrm{mg} / \mathrm{kg}\right.$ i.p.). $\alpha_{1 \mathrm{~B}}$-ARs were stimulated using $\mathrm{NE}(1 \mathrm{mg} / \mathrm{kg}$ i.p. $)$ and the $\alpha_{1 \mathrm{~A}}$-AR antagonist, 5-methyurapidil (10 $\mu \mathrm{g} / \mathrm{kg}$ i.p.). Control mice were injected with saline $(0.9 \% \mathrm{NaCl})$. All mice were injected twice daily for 2 weeks and HW/BW ratios determined. Data represent the mean \pm S.E.M. of $6-8$ mice of equal sexes. $* P<0.05$ (significant difference compared with control).

several studies suggested that ANF transcriptional activity is $\alpha_{1 \mathrm{~A}}$-AR driven (Knowlton et al., 1993; Autelitano and Woodcock, 1998; McWhinney et al., 2000). BNP was only expressed in the double CAM $\alpha_{1 \mathrm{~A} / \mathrm{B}}-\mathrm{AR}$ (Fig. $3 \mathrm{C}$ ). Although BNP is often associated as a marker of hypertrophy and heart failure, exogenous and endogenous application of BNP is antihypertrophic, antifibrotic, and cardioprotective [reviewed in Ritchie et al. (2009)], consistent with the phenotype of the double CAM $\alpha_{1 \mathrm{~A} / \mathrm{B}}-\mathrm{AR}$ mice and is also a novel signal produced through coactivation of the two $\alpha_{1}$-AR subtypes.

Our data suggest that both the CAM $\alpha_{1 \mathrm{~A}}-\mathrm{AR}$ and $\mathrm{CAM} \alpha_{1 \mathrm{~B}}-\mathrm{AR}$ mice develop eccentric hypertrophy (Fig. 5) with both increased posterior wall thickness and chamber dilation, although this takes a longer time to develop in the CAM $\alpha_{1 \mathrm{~B}}$-AR mice and the effect is much milder. Eccentric hypertrophy is often seen with volume and not pressure overload (Spotnitz and Sonnenblick, 1973). Cardiac hypertrophy initially has beneficial effects in terms of muscular economy by normalizing wall stress (i.e., adaptive hypertrophy). However, several studies have demonstrated that chronic hypertrophy can be associated with a significant increase in the risk of heart failure, ischemic heart disease, and apoptosis [i.e., maladaptive hypertrophy; reviewed in Selvetella et al. (2004)]. Several studies have suggested that activation of the $\alpha_{1 \mathrm{~A}} \mathrm{AR}$ but not the $\alpha_{1 \mathrm{~B}}$-AR subtype can be cardioprotective, which indicates a different involvement of the $\alpha_{1}$-AR subtypes in the progression of adaptive to maladaptive hypertrophy [reviewed in Perez and Doze (2011) and Jensen et al. (2011)]. Because IL6-mediated hypertrophy is also adaptive and cardioprotective (Kunisada et al., 2000; Jacoby et al., 2003; Hilfiker-Kleiner et al., 2004; Butler et al., 2006), our results suggest that IL-6 may be partially responsible for cardioprotection seen in the CAM $\alpha_{1 \mathrm{~A}}-\mathrm{AR}$ mouse. In addition, collagen synthesis is an indication of fibrosis, a condition of maladaptive hypertrophy, and only the CAM $\alpha_{1 \mathrm{~B}}-\mathrm{AR}$ mice displayed increased collagen deposition (Fig. 3B). Because collagen synthesis is decreased when STAT3 is inhibited (Mir et al., 2012), this may also explain why the double CAM $\alpha_{1 \mathrm{~A} / \mathrm{B}}-\mathrm{AR}$ mouse inhibited collagen deposition.

Surprisingly, double CAM $\alpha_{1 \mathrm{~A} / \mathrm{B}}-\mathrm{AR}$ transgenic mice did not develop hypertrophy as did the single CAM receptor transgenic mice (Figs. 3 and 5) and hypertrophy was repressed when the opposite $\alpha_{1}$-AR subtype was coactivated in the CAM single receptor mouse models (Figs. 6 and 8). The double CAM $\alpha_{1 \mathrm{~A} / \mathrm{B}}-\mathrm{AR}$ mouse also showed depressed hypertrophic signals for p38, NF- $\kappa \mathrm{B}$, gp130, and p-STAT3 (Figs. 4, 7B, and 8), even less than normal receptors. However, hypertrophy developed in the double CAM $\alpha_{1 \mathrm{~A} / \mathrm{B}}-\mathrm{AR}$ mouse when either receptor subtype was further stimulated (Fig. 6C), suggesting that the regulation of hypertrophy was through signaling per se and not any permanent defect or artifact in the mouse model. Indeed, the inhibition of hypertrophy in the double CAM $\alpha_{1 \mathrm{~A} / \mathrm{B}}-\mathrm{AR}$ seems resultant of the antagonistic hypertrophic signaling changes caused by co-expression and coactivation of the $\alpha_{1 \mathrm{~A}^{-}}$ and $\alpha_{1 \mathrm{~B}}$-ARs. The co-expression of CAM $\alpha_{1 \mathrm{~B}}$-AR essentially blocked the ability of CAM $\alpha_{1 \mathrm{~A}}$-AR mice to secrete IL-6 (Fig. 7A). Likewise, the co-expression of the CAM $\alpha_{1 \mathrm{~A}}-\mathrm{AR}$ blocked the ability of the CAM $\alpha_{1 \mathrm{~B}}-\mathrm{AR}$ mice to activate NF- $\kappa \mathrm{B}$ (Fig. 4). Whereas inhibition of particular signals has been previously shown to reverse hypertrophy, this is the first report of co-receptor activation mediating the same effect.

Mechanistically, inhibition of p38 and NF- $\kappa \mathrm{B}$ signaling in the double CAM $\alpha_{1 \mathrm{~A} / \mathrm{B}}-\mathrm{AR}$ likely downregulated IL- 6 since we have shown that $\alpha_{1}$-AR-mediated IL- 6 expression is regulated through p38 in myocytes (Fig. 8) (Perez et al., 2009). In 
A

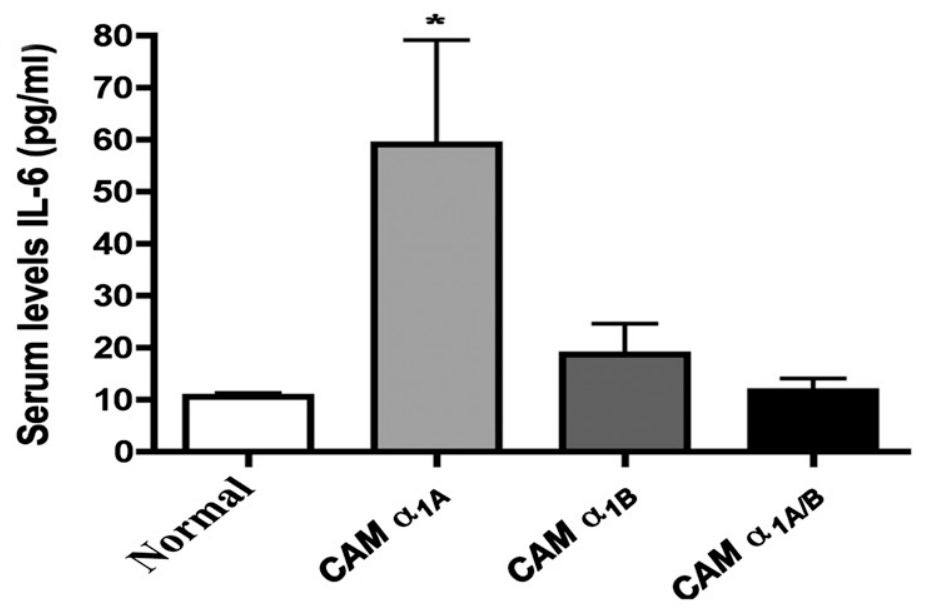

B
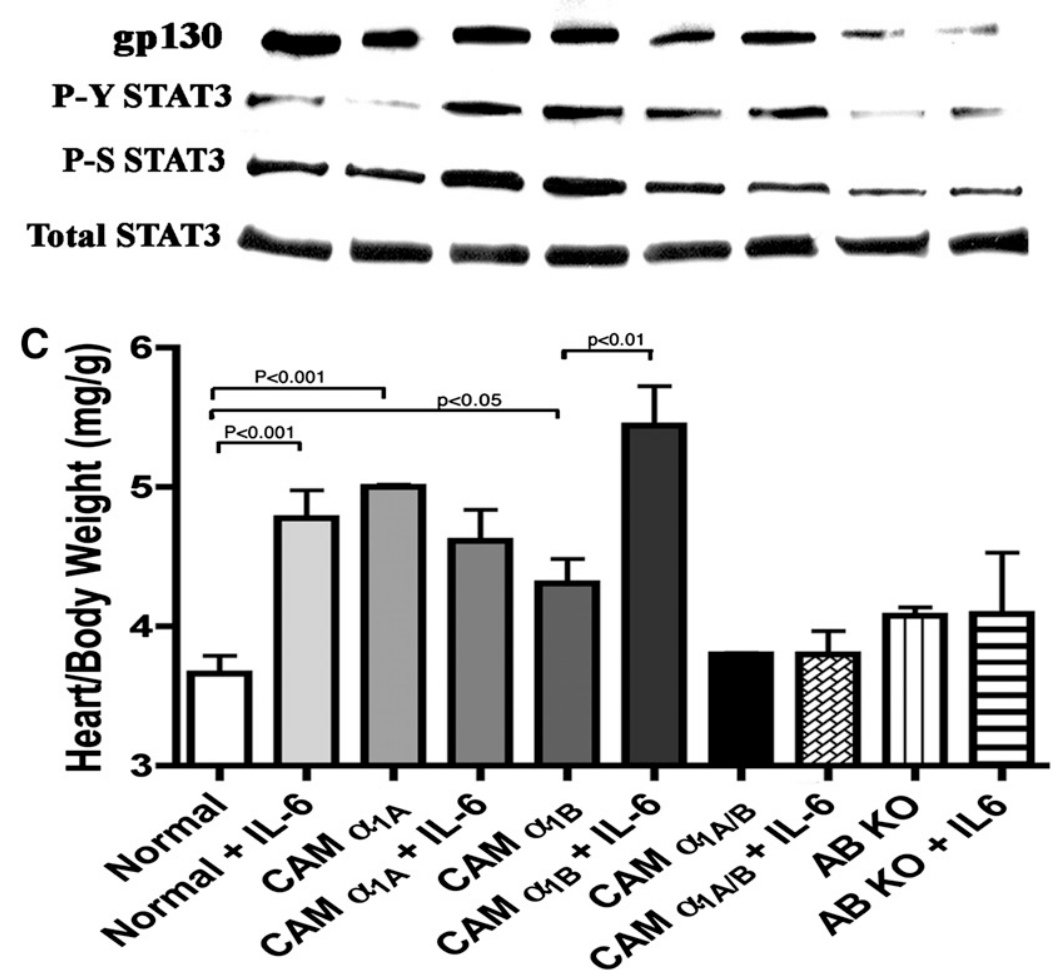

Fig. 7. IL-6/gp130/STAT3 levels and mediated hypertrophy in CAM mice. (A) Serum IL-6 was determined using the Quantikine mouse kit following the manufacturer's instructions. (B) Levels of gp130, phosphorylated, and total STAT3 as assessed by Western blot. (C) Mice were injected daily for 2 weeks i.p. with IL-6 $(0.1 \mathrm{ml}, 40 \mathrm{ng})$ and HW/BW ratios determined. Data represent the mean \pm S.E.M. of $4-6$ mice of equal sexes. ${ }^{*} P<0.05$ (significant difference compared with nontransgenic mice). fact, both p38 and NF- $\kappa$ B regulate IL-6 expression and release in myocytes (Craig et al., 2000). Gp130 may downregulate through $\alpha_{1}$-AR signaling due to gp130 phosphorylation by CaM kinases that target Ser782 to increase its internalization (Gibson et al., 2005).

One intriguing possibility is that heterodimer signaling of the $\alpha_{1}$-AR subtypes is the initial step that suppresses hypertrophic signals (Fig. 8). There is precedence for this paradigm in various $G$ protein-coupled receptor heterodimers that allow either mutually opposite, decreased signaling, or promoted novel signaling pathways (Jordan and Devi, 1999; Jordan et al., 2003; Stanasila et al., 2003; Hague et al., 2006; Rediger et al., 2011). $\alpha_{1 \mathrm{~A}^{-}}$and $\alpha_{1 \mathrm{~B}^{-}} \mathrm{ARs}$ have been shown to form heterodimers (Stanasila et al., 2003) and novel functional activities (Hague et al., 2006). Under physiologic conditions, the heart contains a disproportionate ratio of the $\alpha_{1}$-AR subtypes. The rodent and human heart expresses approximately a 70/30 ratio in receptor density for the $\alpha_{1 \mathrm{~B}^{-}}$and $\alpha_{1 \mathrm{~A}} \mathrm{AR}$ subtypes (5-6) that may allow endogenous catecholamines to induce hypertrophy in vivo via a single $\alpha_{1}$-AR subtype.

Our results are consistent with the theory that there are different signals mediating cardiac hypertrophy between the $\alpha_{1 \mathrm{~A}}-\mathrm{AR}$ and $\alpha_{1 \mathrm{~B}}-\mathrm{AR}$. There is a prominent role of IL- 6 in mediating $\alpha_{1 \mathrm{~A}^{-}} \mathrm{AR}$ hypertrophy. Coactivation of $\alpha_{1 \mathrm{~A}^{-}}$and $\alpha_{1 \mathrm{~B}} \mathrm{ARs}$ results in antagonistic hypertrophic signaling for p38, NF- $\kappa$, gp130, and STAT3 (Fig. 8) that besides verifying the importance of the IL- 6 pathway in $\alpha_{1}$-AR-mediated hypertrophy, may offer an alternative therapeutic strategy for heart failure once sufficiently selective $\alpha_{1}$-AR agonists are developed. 


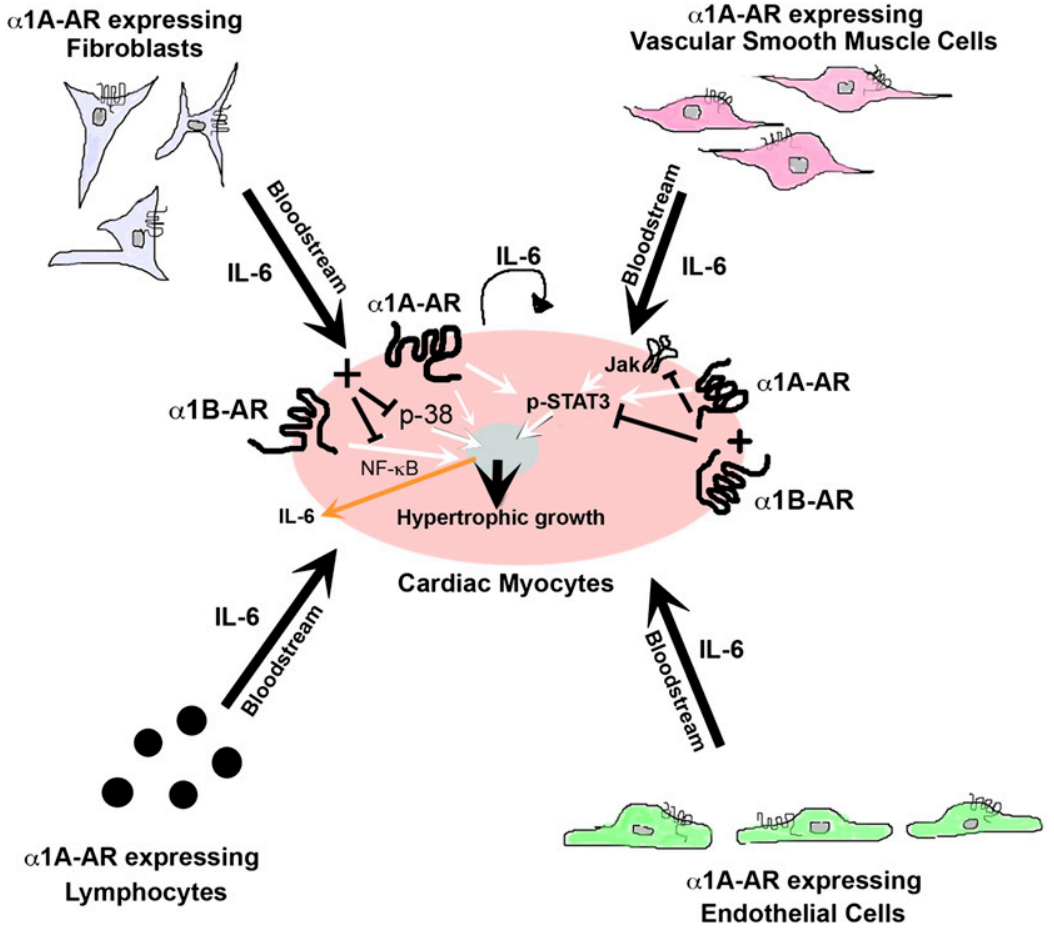

Fig. 8. Schematic of $\alpha_{1 \mathrm{~A}}-\mathrm{AR}$-mediated cardiac hypertrophy and antagonistic hypertrophic signaling initiated with coactivation with the $\alpha_{1 \mathrm{~B}} \mathrm{AR} . \alpha_{1 \mathrm{~A}}$-ARs mediate the secretion of IL- 6 into the bloodstream from various cell types such as myocytes, vascular smooth muscle cells, fibroblasts, lymphocytes, and endothelial cells. The secreted IL-6 acts on the myocyte to mediate cardiac hypertrophy through STAT3 nuclear signaling. $\alpha_{1 \mathrm{~A}}$-ARs also phosphorylate STAT3 independent of IL- 6 secretion. $\alpha_{1 \mathrm{~B}}$-ARs mediate hypertrophic NF- $\kappa \mathrm{B}$ signaling. When $\alpha_{1 \mathrm{~A}^{-}}$and $\alpha_{1 \mathrm{~B}^{-}} \mathrm{ARs}$ are coexpressed and coactivated, hypertrophic signals through p38, NK- $\kappa$ B, and STAT3 are inhibited. Inhibition of both p38 and NF- $\kappa \mathrm{B}$ downregulate the expression and secretion of IL- 6 from the myocyte.

\section{Acknowledgments}

The authors thank Paul Simpson for the AB KO mice.

\section{Authorship Contributions}

Participated in research design: Papay, Shi, Piascik, Naga Prasad, Perez.

Conducted experiments: Papay, Shi, Piascik, Naga Prasad.

Performed data analysis: Papay, Shi, Piascik, Naga Prasad, Perez.

Wrote or contributed to the writing of the manuscript: Papay, Shi, Naga Prasad, Perez.

\section{References}

Autelitano DJ and Woodcock EA (1998) Selective activation of $\alpha_{1 \mathrm{~A}}$-adrenergic receptors in neonatal cardiac myocytes is sufficient to cause hypertrophy and differential regulation of $\alpha_{1}$-adrenergic receptor subtype mRNAs. $J$ Mol Cell Cardiol 30:1515-1523

Butler KL, Huffman LC, Koch SE, Hahn HS, and Gwathmey JK (2006) STAT-3 activation is necessary for ischemic preconditioning in hypertrophied myocardium. Am J Physiol Heart Circ Physiol 291:H797-H803.

Cavalli A, Lattion AL, Hummler E, Nenniger M, Pedrazzini T, Aubert JF, Michel MC, Yang M, Lembo G, and Vecchione C et al. (1997) Decreased blood pressure response in mice deficient of the $\alpha_{1 b}$-adrenergic receptor. Proc Natl Acad Sci USA 94:11589-11594.

Clerk A, Michael A, and Sugden PH (1998) Stimulation of the p38 mitogen-activated protein kinase pathway in neonatal rat ventricular myocytes by the G proteincoupled receptor agonists, endothelin-1 and phenylephrine: a role in cardiac myocyte hypertrophy? J Cell Biol 142:523-535.

Cotecchia S, Schwinn DA, Randall RR, Lefkowitz RJ, Caron MG, and Kobilka BK (1988) Molecular cloning and expression of the cDNA for the hamster $\alpha{ }_{1}$-adrenergic receptor. Proc Natl Acad Sci USA 85:7159-7163.

Craig R, Larkin A, Mingo AM, Thuerauf DJ, Andrews C, McDonough PM, and Glembotski CC (2000) p38 MAPK and NF-kappa B collaborate to induce interleukin-6 gene expression and release. Evidence for a cytoprotective autocrine signaling pathway in a cardiac myocyte model system. J Biol Chem 275: $23814-23824$.

Faber JE, Yang N, and Xin X (2001) Expression of $\alpha$-adrenoceptor subtypes by smooth muscle cells and adventitial fibroblasts in rat aorta and in cell culture. $J$ Pharmacol Exp Ther 298:441-452.

Gibson RM, Laszlo GS, and Nathanson NM (2005) Calmodulin-dependent protein kinases phosphorylate gp130 at the serine-based dileucine internalization motif. Biochim Biophys Acta 1714:56-62.

Gonzalez-Cabrera PJ, Gaivin RJ, Yun J, Ross SA, Papay RS, McCune DF, Rorabaugh BR, and Perez DM (2003) Genetic profiling of $\alpha 1$-adrenergic receptor subtypes by oligonucleotide microarrays: coupling to interleukin-6 secretion but differences in STAT3 phosphorylation and gp-130. Mol Pharmacol 63:1104-1116.
Grisanti LA, Woster AP, Dahlman J, Sauter ER, Combs CK, and Porter JE (2011) $\alpha_{1-}$ adrenergic receptors positively regulate Toll-like receptor cytokine production from human monocytes and macrophages. J Pharmacol Exp Ther 338:648-657.

Grupp IL, Lorenz JN, Walsh RA, Boivin GP, and Rindt H (1998) Overexpression of $\alpha_{1 \mathrm{~B}}$-adrenergic receptor induces left ventricular dysfunction in the absence of hypertrophy. Am J Physiol 275:H1338-H1350.

Hague C, Lee SE, Chen Z, Prinster SC, Hall RA, and Minneman KP (2006) Heterodimers of $\alpha_{1 \mathrm{~B}^{-}}$and $\alpha_{1 \mathrm{D}^{-}}$-adrenergic receptors form a single functional entity. Mol Pharmacol 69:45-55.

Hilfiker-Kleiner D, Hilfiker A, Fuchs M, Kaminski K, Schaefer A, Schieffer B, Hillmer A, Schmiedl A, Ding Z, and Podewski E et al. (2004) Signal transducer and activator of transcription 3 is required for myocardial capillary growth, control of interstitial matrix deposition, and heart protection from ischemic injury. Circ Res 95:187-195.

Hirasawa A, Tsumaya K, Awaji T, Shibata K, Homma N, Shinomiya T, and Tsujimoto G (1996) Flow cytometry analysis of $\alpha_{1}$-adrenoceptor subtypes. FEBS Lett 386 : 141-148.

Hirota H, Yoshida K, Kishimoto T, and Taga T (1995) Continuous activation of gp130, a signal-transducing receptor component for interleukin 6-related cytokines, causes myocardial hypertrophy in mice. Proc Natl Acad Sci USA 92: $4862-4866$.

Hirotani S, Otsu K, Nishida K, Higuchi Y, Morita T, Nakayama H, Yamaguchi O, Mano T, Matsumura $\mathrm{Y}$, and Ueno $\mathrm{H}$ et al. (2002) Involvement of nuclear factorkappaB and apoptosis signal-regulating kinase 1 in G-protein-coupled receptor agonist-induced cardiomyocyte hypertrophy. Circulation 105:509-515.

Jacoby JJ, Kalinowski A, Liu MG, Zhang SS, Gao Q, Chai GX, Ji L, Iwamoto Y, Li E, and Schneider M et al. (2003) Cardiomyocyte-restricted knockout of STAT3 results in higher sensitivity to inflammation, cardiac fibrosis, and heart failure with advanced age. Proc Natl Acad Sci USA 100:12929-12934.

Jensen BC, O'Connell TD, and Simpson PC (2011) $\alpha-1$-adrenergic receptors: targets for agonist drugs to treat heart failure. $J \mathrm{Mol}$ Cell Cardiol 51:518-528.

Jensen BC, Swigart PM, Montgomery MD, and Simpson PC (2010) Functional $\alpha-1 \mathrm{~B}$ adrenergic receptors on human epicardial coronary artery endothelial cells. Naunyn Schmiedebergs Arch Pharmacol 382:475-482.

Jordan BA and Devi LA (1999) G-protein-coupled receptor heterodimerization modulates receptor function. Nature 399:697-700.

Jordan BA, Gomes I, Rios C, Filipovska J, and Devi LA (2003) Functional interactions between mu opioid and $\alpha_{2 \mathrm{~A}}$-adrenergic receptors. Mol Pharmacol 64: 1317-1324.

Knowlton KU, Michel MC, Itani M, Shubeita HE, Ishihara K, Brown JH, and Chien KR (1993) The $\alpha$ 1A-adrenergic receptor subtype mediates biochemical, molecular, and morphologic features of cultured myocardial cell hypertrophy. J Biol Chem 268:15374-15380.

Kunisada K, Hirota H, Fujio Y, Matsui H, Tani Y, Yamauchi-Takihara K, and Kishimoto T (1996) Activation of JAK-STAT and MAP kinases by leukemia inhibitory factor through gp130 in cardiac myocytes. Circulation 94:2626-2632.

Kunisada K, Negoro S, Tone E, Funamoto M, Osugi T, Yamada S, Okabe M, Kishimoto T, and Yamauchi-Takihara K (2000) Signal transducer and activator of transcription 3 in the heart transduces not only a hypertrophic signal but a protective signal against doxorubicin-induced cardiomyopathy. Proc Natl Acad Sci USA 97:315-319. 
Lemire I, Ducharme A, Tardif JC, Poulin F, Jones LR, Allen BG, Hébert TE, and Rindt $\mathrm{H}$ (2001) Cardiac-directed overexpression of wild-type $\alpha_{1 \mathrm{~B}}$-adrenergic receptor induces dilated cardiomyopathy. Am J Physiol Heart Circ Physiol 281: H931-H938.

Lin F, Owens WA, Chen S, Stevens ME, Kesteven S, Arthur JF, Woodcock EA Feneley MP, and Graham RM (2001) Targeted $\alpha(1 \mathrm{~A})$-adrenergic receptor overexpression induces enhanced cardiac contractility but not hypertrophy. Circ Res 89:343-350.

Loppnow H and Libby P (1990) Proliferating or interleukin 1-activated human vascular smooth muscle cells secrete copious interleukin 6 . J Clin Invest 85:731-738.

McWhinney C, Wenham D, Kanwal S, Kalman V, Hansen C, and Robishaw JD (2000) Constitutively active mutants of the $\alpha\left({ }_{1 \mathrm{a}}\right)$ - and the $\alpha\left({ }_{1 \mathrm{~b}}\right)$-adrenergic receptor subtypes reveal coupling to different signaling pathways and physiological responses in rat cardiac myocytes. $J$ Biol Chem 275:2087-2097.

Meier H, Bullinger J, Marx G, Deten A, Horn LC, Rassler B, Zimmer HG, and Briest W (2009) Crucial role of interleukin-6 in the development of norepinephrineinduced left ventricular remodeling in mice. Cell Physiol Biochem 23:327-334

Michel MC, Hanft G, and Gross G (1994) Radioligand binding studies of $\alpha_{1}{ }^{\text {-adre- }}$ noceptor subtypes in rat heart. Br J Pharmacol 111:533-538.

Michel MC and Insel PA (1994) Comparison of cloned and pharmacologically defined rat tissue $\alpha_{1}$-adrenoceptor subtypes. Naunyn Schmiedebergs Arch Pharmacol $\mathbf{3 5 0}$ 136-142.

Milano CA, Dolber PC, Rockman HA, Bond RA, Venable ME, Allen LF, and Lefkowitz RJ (1994) Myocardial expression of a constitutively active $\alpha{ }_{1 B}$-adrenergic receptor in transgenic mice induces cardiac hypertrophy. Proc Natl Acad Sci USA 91: 10109-10113.

Mir SA, Chatterjee A, Mitra A, Pathak K, Mahata SK, and Sarkar S (2012) Inhibition of signal transducer and activator of transcription 3 (STAT3) attenuates interleukin-6 (IL-6)-induced collagen synthesis and resultant hypertrophy in rat heart. $J$ Biol Chem 287:2666-2677.

Nemoto S, Sheng Z, and Lin A (1998) Opposing effects of Jun kinase and p38 mitogen-activated protein kinases on cardiomyocyte hypertrophy. Mol Cell Biol 18 $3518-3526$

O'Connell TD, Rokosh DG, and Simpson PC (2001) Cloning and characterization of the mouse $\alpha_{1 \mathrm{C} / \mathrm{A}}$-adrenergic receptor gene and analysis of an $\alpha_{1 \mathrm{C}}$ promoter in cardiac myocytes: role of an MCAT element that binds transcriptional enhancer factor-1 (TEF-1). Mol Pharmacol 59:1225-1234.

O'Connell TD, Swigart PM, Rodrigo MC, Ishizaka S, Joho S, Turnbull L, Tecott LH, Baker AJ, Foster E, and Grossman W et al. (2006) $\alpha_{1}$-adrenergic receptors prevent a maladaptive cardiac response to pressure overload. J Clin Invest 116:1005-1015.

Perez DM and Doze VA (2011) Cardiac and neuroprotection regulated by $\alpha\left({ }_{1}\right)$-adrenergic receptor subtypes. J Recept Signal Transduct Res 31:98-110.

Perez DM, Papay RS, and Shi T (2009) alpha1-Adrenergic receptor stimulates interleukin-6 expression and secretion through both mRNA stability and transcriptional regulation: involvement of p38 mitogen-activated protein kinase and nuclear factor-kappaB. Mol Pharmacol 76:144-152.

Perez DM, Piascik MT, and Graham RM (1991) Solution-phase library screening for the identification of rare clones: isolation of an $\alpha_{1 \mathrm{D}}$-adrenergic receptor $\mathrm{cDNA} . \mathrm{Mol}$ Pharmacol 40:876-883.

Perez DM, Piascik MT, Malik N, and Gaivin RJ, andGraham RM (1994) Cloning, expression, and tissue distribution of the rat homolog of the bovine $\alpha_{1 \mathrm{C}}$-adrenergic receptor provide evidence for its classification as the $\alpha_{1 \mathrm{~A}}$ subtype. Mol Pharmacol 46:823-831.

Rediger A, Piechowski CL, Yi CX, Tarnow P, Strotmann R, Grüters A, Krude H, Schöneberg T, Tschöp MH, and Kleinau G et al. (2011) Mutually opposite signal modulation by hypothalamic heterodimerization of ghrelin and melanocortin-3 receptors. J Biol Chem 286:39623-39631.
Ritchie RH, Rosenkranz AC, and Kaye DM (2009) B-type natriuretic peptide: endogenous regulator of myocardial structure, biomarker and therapeutic target. Curr Mol Med 9:814-825.

Rokosh DG, Stewart AF, Chang KC, Bailey BA, Karliner JS, Camacho SA, Long CS, and Simpson PC (1996) $\alpha_{1}$-adrenergic receptor subtype mRNAs are differentially regulated by $\alpha_{1}$-adrenergic and other hypertrophic stimuli in cardiac myocytes in culture and in vivo. Repression of $\alpha_{1 \mathrm{~B}}$ and $\alpha_{1 \mathrm{D}}$ but induction of $\alpha_{1 \mathrm{C}}$.J Biol Chem 271:5839-5843.

Rorabaugh BR, Ross SA, Gaivin RJ, Papay RS, McCune DF, Simpson PC, and Perez $\mathrm{DM}(2005) \alpha 1 \mathrm{~A}$ - but not $\alpha 1 \mathrm{~B}$-adrenergic receptors precondition the ischemic heart by a staurosporine-sensitive, chelerythrine-insensitive mechanism. Cardiovasc Res 65:436-445.

Selvetella G, Hirsch E, Notte A, Tarone G, and Lembo G (2004) Adaptive and maladaptive hypertrophic pathways: points of convergence and divergence. Cardiovasc Res 63:373-380.

Shi T, Papay RS, and Perez DM (2012) $\alpha(1 \mathrm{~A})$-adrenergic receptor differentially regulates STAT3 phosphorylation through PKC $\epsilon$ and PKC $\delta$ in myocytes. $J$ Recept Signal Transduct Res 32:76-86.

Simpson P (1983) Norepinephrine-stimulated hypertrophy of cultured rat myocardial cells is an $\alpha_{1}$ adrenergic response. $J$ Clin Invest 72:732-738.

Spotnitz HM and Sonnenblick EH (1973) Structural conditions in the hypertrophied and failing heart. Am $J$ Cardiol 32:398-406.

Stanasila L, Perez JB, Vogel H, and Cotecchia S (2003) Oligomerization of the $\alpha_{1 \mathrm{a}}$ and $\alpha 1 \mathrm{~b}$-adrenergic receptor subtypes. Potential implications in receptor internalization. I Biol Chem 278:40239-40251.

Tayebati SK, Bronzetti E, Morra Di Cella S, Mulatero P, Ricci A, Rossodivita I, Schena M, Schiavone D, Veglio F, and Amenta F (2000) In situ hybridization and immunocytochemistry of $\alpha_{1}$-adrenoceptors in human peripheral blood lymphocytes. J Auton Pharmacol 20:305-312.

Wang BH, Du XJ, Autelitano DJ, Milano CA, and Woodcock EA (2000) Adverse effects of constitutively active $\alpha(1 \mathrm{~B})$-adrenergic receptors after pressure overload in mouse hearts. Am J Physiol Heart Circ Physiol 279:H1079-H1086.

Yamauchi-Takihara K, Ihara Y, Ogata A, Yoshizaki K, Azuma J, and Kishimoto T (1995) Hypoxic stress induces cardiac myocyte-derived interleukin-6. Circulation 91:1520-1524.

Yun J, Zuscik MJ, Gonzalez-Cabrera P, McCune DF, Ross SA, Gaivin R, Piascik MT, and Perez DM (2003) Gene expression profiling of $\left.\alpha{ }_{1 \mathrm{~b}}\right)$-adrenergic receptor-induced cardiac hypertrophy by oligonucleotide arrays. Cardiovasc Res 57:443-455.

Zechner D, Thuerauf DJ, Hanford DS, McDonough PM, and Glembotski CC (1997) A role for the p38 mitogen-activated protein kinase pathway in myocardial cell growth, sarcomeric organization, and cardiac-specific gene expression. J Cell Biol 139:115-127.

Zuscik MJ, Chalothorn D, Hellard D, Deighan C, McGee A, Daly CJ, Waugh DJJ, Ross SA, Gaivin RJ, and Morehead AJ et al. (2001) Hypotension, autonomic failure, and cardiac hypertrophy in transgenic mice overexpressing the $\alpha_{1 \mathrm{~B}}$-adrenergic receptor. J Biol Chem 276:13738-13743.

Zuscik MJ, Piascik MT, and Perez DM (1999) Cloning, cell-type specificity, and regulatory function of the mouse $\alpha(1 \mathrm{~B})$-adrenergic receptor promoter. Mol Pharmacol 56:1288-1297.

Zuscik MJ, Sands S, Ross SA, Waugh DJJ, Gaivin RJ, Morilak D, and Perez DM (2000) Overexpression of the $\alpha 1 \mathrm{~B}$-adrenergic receptor causes apoptotic neurodegeneration: multiple system atrophy. Nat Med 6:1388-1394.

Address correspondence to: Dr. Dianne M. Perez, Department of Molecular Cardiology, Lerner Research Institute, Cleveland Clinic Foundation, NB50, 9500 Euclid Ave., Cleveland, OH 44195. E-mail: perezd@ccf.org 